\title{
REFORMS IN HIGH EDUCATION AND THEIR INFLUENCE IN ECONOMIC DEVELOPMENT OF R. MACEDONIA
}

\author{
Jeton Shaqiri, \\ International University of Struga - R.Macedonia \\ (j.shaqiri@eust.edu.mk)
}

Original Scientific Paper

doi:10.5937/jouproman5-15070

\begin{abstract}
Education as an important social activity represents the basic capital of contemporary society and, as such, today is considered to be a major factor in the economic and social development of any country. The development of education during the transition period in our country has marked significant and visible changes. The importance of education in the economic and social development of each country is one of the topics around the world discussed in various aspects.
\end{abstract}

Investing in education is quite remarkable, because it is an investment in knowledge, technology, science - "brain drain", a future investment and is one of the decisive factors for today's socio-economic development with current changes and current global development.

Due to education, in some countries are made great scientific discoveries and technicallytechnological revolutions, which have been crucial to humanity in general. In fact, education is knowledge and knowledge is the driving force behind the overall development of a society. Worldrenowned economists such as Adam Smith and Alfred Marshall in the 18th and 19th centuries were concerned with investment in education, posing the question: How do investments in education reflect in national wealth? And in increasing the possibility for greater profits of people as individuals! Although, even world-renowned economists have dealt with this issue, which based on empirical data provided explanations on the importance of mediation and economic growth.

Considering that even developing and newest technological innovations derive from the process of educated individuals, it is very important to consider the impact of higher education on economic development.
Keywords: Economic Growth, High Education, GDP, Employment and Unemployment

\section{Theoretical approach to the role of higher education in economic growth}

Higher education is an important form of investment in the development of human capital and is considered as the "engine of development in the economy of the country". Higher education contributes to economic growth through private and public channels. Benefits for individuals include the best prospects for employment, higher salaries, and greater training to save and invest. This may result in a level and quality for improving living. The amount of investment in education differs from country to country, depending on the economic potential and the priorities and policies that the country has designated. According to the data, the US is the state that most allocates money for education. However, an important indicator is certainly the percentage of gross domestic product (GDP) allocated to the education development of each country of the world, and especially the absolute amount of financial resources.

Now, when the role of education in the overall economic and social development of each country is understood, efforts are made to invest as much in it as possible. 
As is well known, educational investments include the budget devoted to the construction and renovation of educational facilities, the purchase of laboratory equipment, the regulation of infrastructure and external environment, the provision of teachers' salaries, the separation of various student and student allowances, the reformation and revision of plans and curricula, creation of mobility opportunities, etc. In particular, investments should be in the function of increasing the quality of education, since this ensures sustainable economic development.

Easterlin states that by 1850 very few people outside of Northwestern Europe and the United States had had any formal education. In Africa and many countries in Asia and Latin America, this lack of education has been present until 1940. The highest level of education makes workers able to adapt more easily and quickly in a new job, but at the same time have greater communication skills. Education also affects the growth of the standard of living in general, of course, by the fact that the educated man knows how to adjust his life better, under the same conditions. No country has managed to have a constant economic development without investments significant in human capital.

The overwhelming development of science and technology has brought the idea of lifelong learning and the inclusion of the population into this. However, different countries are distinguished not only by the size or the mass, but also by the quality of higher education.

If one favors imitation or other channels through which education affects growth, one might note that, in the thirty years after World War II, Europe grew faster than the U.S. even though it invested mainly in primary and secondary education. Similarly, the "Asian miracle" (high productivity growth in Asian countries like South Korea) is associated more with investments in primary and secondary education than with investments in higher education. Examining crosscountry correlations, Krueger and Lindahl (2001) conclude that "[overall,] education [is] statistically significantly and positively associated with subsequent growth only for the countries with the lowest education."

It is impossible to do justice to existing models of education and growth in a few sentences, but we must identify some key precursors. Early on, Nelson and Phelps (1966) argued that a more educated labor force would imitate frontier technology faster.The further a state was from the frontier, the greater the benefits of this catch-up. Benhabib and Spiegal (1994) expanded on their work, arguing that a more educated labor force would also innovate faster. Lucas (1988) and Mankiw, Romer, and Weil (1992) observed that the accumulation of human capital could increase the productivity of other factors and thereby raise growth. ${ }^{1}$

\section{High education in the $R$. Macedonia}

In R. Macedonia there are 19 institutions of higher education taking into consideration and data from the Institute of Statistics in R. Macedonia, the number of students who are graduated during the academic year 2016 decreased by $2.5 \%$ compared to 2015. During 2013, R. Macedonia has 9166 graduate students, in 2014 the number of graduate students was 9662 and in 2015 was 8116 and during $2016-7947$.

\footnotetext{
1 In the Lucas and Mankiw, Romer, and Weil models, a state's rate of growth depends 5 on the rate of accumulation of human capital. Ha and Howitt (2005) point out that such models are hard to reconcile with a state like that U.S., which has sustained growth despite a slowing of its rate of accumulation of human capital.
} 
According to the data of the Ministry of Education for recent years the number of graduates who enroll in faculties ranges from $55 \%$ to $70 \%$, and one of these reasons is the fact that secondary vocational education schools and a number of graduates who complete secondary education do not have a branch or profile through which they can compete in the labor market. At the moment, many attractive study programs are: business, justice, information technology and enrollments in these branches have a significant increase.

It is not easy to give a definite answer to this. Both findings have their advantages and weaknesses. From the first point of view, in order for a country to have economic and social development, the basis for them must be the educated man in quality education institutions. From the second point of view, if not invested in education then quality is also difficult to achieve. There should be higher salaries for teachers, greater funding for research and analysis, investment in labs and information technology so that economic development can increase the quality of education, and this can only be achieved if the state budget has sufficient resources for investment in education. Above all, quality education can have a greater impact on economic development rather than economic development in quality education.

\section{Quality education and its impact on the development of the country}

Reforms in higher education should be guided by the motto: what important impact will it bring to the country's expected developments? Reform becomes meaningful when it contributes to the country's economic and democratic development and gives greater stimulus to its future European integration. The qualitative change in education that took place on the world scale in the last century as a result of the substitution of the alternative: the economy in the function of education with the alternative: education in the function of economic and social development. This approach becomes more important after the global financial crisis in the $21^{\text {st }}$ century in developed countries, much more for R.Macedonia.

If we analyze the factors that have determined our current development, it is noticed that the Macedonian economy has not supported the development of innovations and technology, but in policies for maintaining macroeconomic stability, as well as in remittance-based or informal economy-based development, a situation that was faced with the quality of human resources inherited from the past system. The annual increase of GDP by 2014 was higher than that of domestic savings, which appear at the level of deposits. This margin (the average annual increase of GDP over the average annual increase of deposits) in fact reflects the high level of income from remittances and the informal economy, which could allow cacophony in the program for the development of higher education (massive as well as qualitative).

But Macedonia can no longer support the development just for the factors mentioned above, because another economic situation is emerging, when remittances have dropped significantly from year to year and as lawmakers, they will be even more so in the future. The informal economy will definitely go towards reducing, as a condition of integrating reform. Revenues from donations from international financial institutions are moving towards diminishing; customs incomes in terms of integration fall; external debt has increased a lot and should be paid. In the last two years, bank deposits have not only increased above the GDP but have stagnated. 


\section{Education as an alternative to the country's economic development}

Time requires Macedonia to prepare rapidly to move from its current form of development to another form of development based on quality human resources. Quality in education or education alternatives in function of economic and social development will be the solution for Macedonia as well as in developed countries that have gone on the same way.

This requires greater autonomy in universities, so that they define admission criteria, as in many universities in the world, rather than populist goals, which do not serve the country's development interests. To this end, we need to start drafting a new law on higher education, with the participation and consultation of all actors and political forces, a law that will increase the breathing and autonomy of our universities, to deliver a positive long-awaited product: enhancing quality in higher education.

The reform of higher education in the virtual world of universal higher education, to target the true world of education according to market demands. This requires encouraging debate over a radical reform of education in the country, because education products have longlasting effects and is a sensitive issue for everyone. For this reform it takes its time and should be a reform involving all interest groups.

The real contribution of education to the economy (i.e. GDP) is estimated indirectly through the indicators of the degree of inclusion in the labor market of students who complete the studies. But we still lack cross-sectorial analysis of the labor market and education and its contribution to economic growth. Time increases the need for genuine studies on the labor market in different sectors. Census data of 2011 are a gold mine to carry out cross-analysis by age groups, education and employment.
An inter-institutional cooperation (including universities) would be a rational proposition to "concretely" find out how many schools have ended and how many of them are at work, for example. from graduates of law, economics, medicine, engineering, teaching etc. The data obtained from these studies would more rationally orient the new requirements for higher education studies, avoiding branches where the market is overpopulated.

\subsection{Scientific research}

The debate about a qualitative change in higher education is required to address change in the quality of knowledge, challenging accelerating development. Success in this higher education challenge will depend on the commitment, but also the team's ability and professionalism to lead the change in the sector.

Currently, the debate in America is addressing the issue of investments in higher education, investments not just in the physical infrastructure of universities, but mainly in the quality of the professorship and scientific research as its product, with the hypothesis: as if $1 \%$ of GDP was invested more in education, the crisis would have been avoided. Even in Europe, the economic crisis has spurred the debate on a new model of development in the European economy to restore growth to $4-5 \%$ of GDP, by stimulating new ideas in the economy.

Even more serious and complex is the fair addressing of this issue to Macedonia through higher education through reform that can not succeed without emphasis on genuine scientific research. It is time for master theses, doctoral theses, scientific conferences, and various publications to address the concrete problems that our development develops in different fields, thus solving critical problems. 
This makes university co-operation with public and private entities indispensable. In this sense, the different working groups, created with the participation of the professors, would be really functional.

Real scientific research is the true dimension of the values that our high education carries and which the society is worth investing in. Student work should also become part of the research in the work with their pedagogues, where they learn and contribute simultaneously. This skill can not be equally enjoyed by all students, but only by those qualitative, while others are not necessarily able to graduate and even less pass to the second or third stage of studies. Because it costs the student and the society, so in these phases the school should be more selective.

A qualitative reform in knowledge would require the empowerment of scientific research institutions, which the previous reform had atrophied. We are among the rare countries that we do not have a genuine institute of economic studies.

In conditions when economic growth is a function of production, in the conditions when Macedonia does not produce technology, our high education should address the quantity, but more the quality of human capital development, to achieve the expected economic development of a country that aspires to the EU.

\section{Conclusion}

and

\section{Recommendations}

High quality education will contribute to increased proactivity and competitiveness as well as to achieve economic growth. Higher education is a determinant not only of faster and higher economic development but more qualitative as well (through technological development, innovation and other in science) therefore it is a positive contributor to revenue growth and to produce benefits both public and private. Higher education can create higher income for the state, through taxes it can increase savings and investments. Education can also improve a country's health system, contribute to reduced population growth, improve technology, and strengthen good governance.

Achieving synergies between providing alternatives to universities and their enforceability by state institutions without doubts requires a greater supporting role. Continuing the upgrading of higher education from the point of view of standards and quality, accreditation and prosecution processes, wider involvement in their study and scientific work, the cooperation of university and postgraduate studies with those of European and world countries, is a process that I call for a broad consensus and support, since the ultimate goal is to increase economic and social development.

Macedonia needs more in this stage: Clearer rules in the functioning of higher education and fair competition, education spending to be not less than $5 \%$ of GDP, greater education development professional competency for the provision of knowledgeable students and skills to enhance competitiveness and skills needed to cope with the challenges of the $21^{\text {st }}$ century, Correct application of fiscal legislation on education, Incentive application research and innovation, Policy on building the necessary infrastructure, Developing Time-bound Information Technology and Clear Fiscal Policies for Supporting and Building University Environments and Inclusion of Universities in International Projects and Linking Higher Education with the Regional and International Marketplace to Fiscal Policy Incentives in Supporting New Graduates from foreign universities. 


\section{Bibliography}

[1] Angrist, Joshua D. and Alan B. Krueger (1991). Does Compulsory Schooling Attendance Affect Schooling and Earnings? Quarterly Journal of Economics. 106:4, pp. 979-1014.

[2] Barro, Robert J. and Jong-Wha Lee (2010), A New Data Set of Educational Attainment in the World, 19502010, NBER Working Paper No. 15902.

[3] Belzil, Christian and Hansen, Jrgen (2011), Unobserved Ability and the Return to Schooling, IZA Discussion Paper No. 508.

[4] Belzil, Christian and Hansen, Jorgen (2007), A structural analysis of the correlated random coefficient wage regression model, Journal of Econometrics, Elsevier, vol. 140(2), pages 827-848, October.

[5] Belzil, Christian, Hansen, Jorgen and Liu, Xingfei (2011), Dynamic Skill Accumulation, Comparative Advantages, Compulsory Schooling, and Earnings, IZA Discussion Paper No. 6167.

[6] Bils, Mark and Peter J. Klenow (2000), Does Schooling Cause Growth?, American Economic Association, vol. 90(5), pages 1160-1183, December.
[7] Cohen, Daniel and Marcelo Soto (2007), Growth and Human Capital: Good Data, Good Results, OECD Development Centre Working Papers, 179, OECD Publishing.

[8] Harmon, Colm and Ian Walker (1995), Estimates of the Economic Return to Schooling for the United Kingdom, American Economic Review. rev. 85:5 pp. 1278-86.

[9] Klenow, Peter J. and Andres RodriguezClare, Externalities and Growth, Handbook of Economic Growth, in: Philippe Aghion \& Steven Durlauf (ed.), Handbook of Economic Growth, edition 1, volume 1, chapter 11, pages 817-861 Elsevier.

[10]Lutz, Wolfang, Anne Goujon, Samir K.C. and Warren Sanderson (2007), Reconstruction of populations by age, sex and level of educational attainment for 120 countries for 1970-2000, Vienna Yearbook of Population Research 2007, pp. 193235.

[11] Mincer, Jacob (1974), Schooling, Earnings and Experience. NY Columbia U. Press.

[12] Pritchett, Lant (1996), Where Has All the Education Gone? World Bank Policy Research Working Paper No. 1581. 